\title{
A concept "Riphaean Mountains" in ancient geocartography: myth, cosmology, symbol and/or reality?
}

\begin{abstract}
One of the most mysterious concepts in ancient geography are the Riphaean Mountains that had for centuries been the object of mythological, cosmological, geographic, cartographic, and poetic discourses. Having originated as a designation of the northern (in relation to Greece) Thracian mountain, the name in the course of time became attached to the mountains located in the extreme north of the oecumene. Cosmological ideas explaining the rising of the earth's surface to the north, the passage of the sun after sunset through the northern outskirts of the oecumene behind the Riphaean Mountains eastward, and many others were associated with these mountains. In ancient literature the Riphaean Mountains are often associated with a blessed people of the Hyperboreans who seemed to live beyond the Riphaean Mountains in a particularly favorable climate. In this paper the attempts of ancient cartographers to locate the Riphaean Mountains on a geographical map will be considered.
\end{abstract}

Keywords

Riphaean Mountains • ancient cartography • ancient geography

(C) University of Warsaw - Faculty of Geography and Regional Studies

Introduction

Everybody who deals with the ancient and medieval geography of Northern Eurasia encounters the problem of the localization of the mythical (or semi-mythical) Ripaean (in the Latin orthography, often Riphaean) Mountains ('Pıтаí, 'Pїтаa, 'Pímaı

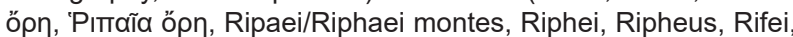
Rifrei, Riffei), supposedly located in the north of Europe (Kiessling 1914; Bekkers 1914). Known to the ancient Greeks in archaic times, the Riphaean Mountains firmly entered ancient man's views of the northern outskirts of the oecumene, most often the northnortheast of Europe. Moreover, throughout the Middle Ages and in the following centuries until the 16th century, the existence of the Riphaean mountains somewhere in Northeast Europe or North Asia was not particularly questionable.

In this paper, I would like to consider briefly the origin, evolution and features of this mythopoetic and geographical concept throughout antiquity.

The Riphaean Mountains as Thracian mountains

Where were the northern mountains in Europe from the point of view of the archaic Greeks? To answer this question, it is necessary to determine what the oecumene looked like at that time. Our analysis of the geographical and cosmological representations of the Homeric Greeks (Podossinov 2015) leads to the conclusion that Europe in this world picture was confined by Greece itself, washed from the east, south and west by sea, and extending indefinitely to the north; it is, practically, the Balkan Peninsula.

In this archaic world picture, the northern horizon of the Greeks was closed by mountainous regions - Pieria, Macedonia,
Alexander Podossinov

Institute for General History of Russian Academy of Sciences, Department of Ancient Languages, Historical Faculty, Lomonosov Moscow State University, Russian Federation e-mail:podossinov@mail.ru

Received: 12 January 2019 Accepted: 17 April 2019
Paeonia and Thrace. The Greeks were familiar with large mountain ranges - Thracian Rhodopes, Pangaion and Haemus. Immediately beyond the mountains was to be either the North Ocean (which surrounded all the land and over which the Argonauts and Odysseus supposedly sailed), or a strip of a land between the mountains and the ocean; even the Ister-Danube was probably not yet known to the Homeric Greeks. Ister was named by Hesiod in the "Theogony" in the famous catalog of rivers (v. 337-345) for the first time. So, then known Europe ended in the north in a certain large mountain range and, in my opinion, these are the mountains that, with the development of acquaintance with the periphery of the oecumene, were moved to the north of Europe and stretch from the Alps to the Urals, preserving their neighborhood with the northern ocean.

In these Thracian mountains, according to ancient myths, the Boreas wind dwelt as a mythical character (a king), which in time became for the Greeks a synonym of the cold, gusty north wind. Boreas as the north wind is already mentioned by Homer (Odyss. V, v. 295); the word Boreas was later used as the designation of the entire north of Europe (see Rausch 2013, pp. 9-14).

With the expansion of the geographical horizon of the Greeks, the mountains that he inhabited "moved" further north, ${ }^{1}$ so Boreas soon began to denote the north in general. The

${ }^{1}$ Regarding this "moving", see Beckers 1914, p. 538: "Da im Laufe der Zeit die Vorstellung vom Bereich des Nordrandes der Erde eine vielfache Wandlung durchmachte, und die umgrenzende Peripherie sich der fortschreitenden Aufhellung nördlicher Erdräume von Fall zu Fall anpassen mußte, so wurden die Rhipäen in späteren Zeiten höher im N(orden) gesucht und angenommen als in früheren"; see also pp. 548-549. Cf. Wikén 1939, pp. 540-552; Stenger 2001, pp. 992-993; Rausch 2013, pp. 16-17. 
connection "between the North Greek mountains and Boreas was also preserved when these mountains "moved" far to the north and when they began to be called Riphaeans.

So if, according to Kallimachos, Boreas lived in the mountains of Thracian Haemus and was famous for his stormy tenderness ('ंınn) and the cold that he brought to Greece, and according to Valerius Flaccus (Argon. I, vv. 574-575) on Pangaion mountain also, then according to Strabo (VII, 3, 1), Pliny the Elder (NH IV, 88) and the same Valerius Flaccus (Argon. II, 516), Boreas already lived in the Riphaean mountains.

For the first time, we find the Riphaean name, without indicating the mountains' localization, in the poem of Alkman in the second half of the 7th century in the form of "Ripas" (F 90 Page: 'Рímas öpos); they are said to be "the bosom of a black

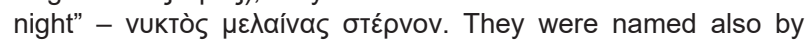
Sophocles in the Oedipus at Colonus as Riphaean and nightly

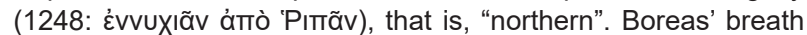
is connected with the etymology of the Riphaean name, popular in antiquity (and accepted by most modern historians) - namely, from the verb ṕímтाı - "throw, drop", and from the noun ṕıтń "onslaught, pressure, rush". Homer already uses the expression ṕıтทे Bopéao (llias XV, 171).

In close connection with the Riphaean Mountains, from which Boreas blows, there is a blissful people of Hyperboreans living in the narrow strip of land between the Riphaeans and the North Ocean in a mild climate, who revere Apollo. ${ }^{2}$ As an example of the combination of these two names, I quote the words of the Hellenistic poet Callimachus, who in his work "Aitia" speaks of "the sons of the Hyperboreans who accompany the gifts from the

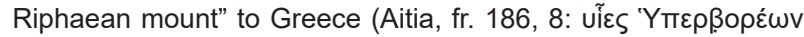
'Pıтrá́ou тв́

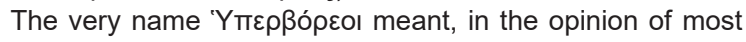
ancient authors, those who live "behind Boreas". Diodorus of Sicily explains this name in the following way: "Hyperboreans are

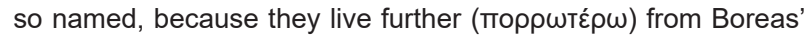
breath" (Diod. II, 47, 1; see also: Mela III, 36; Plin. NH VI, 34; IV, 89; Pomp. Fest. Excerp. 8, 103 M; Vib. Sequester De flum. s. v.; Martian. Capella VI, 664).

Let us note that for the Greeks, who suffered from the cold northern wind of Boreas, the peoples who lived behind it must have seemed blessed, because they were deprived of this destructive breath of the wind.

Contemporary researchers associate this ethnonym with the name of Mount Bora in Thrace, mentioned by Titus Livius (Liv. XLV, 29, 8: Bora mons); and this ancient etymology of Hyperboreans ("behind Boreas") remains one of the most possible (to the etymology of the Greek "Hyperboreoi", see: Macurdy 1916, pp. 180-183; Casson 1920, pp. 1-3; Harmatta 1955/1956, pp. 57-66; Van Windekens 1957, pp. 164-169; Bolton 1962, pp. 195; Romm 1989, pp. 97-113; Werhahn 1994, pp. 968-969).

The Riphaean Mountains "move" far from the Thracia

Since the mountains that moved with time away from Thrace in a fan-like way, and found themselves in different parts of Europe from the Pyrenees and the Alps to the Black Sea, then the "Hyperboreans", who lived "behind" them, eventually settled throughout the whole of Europe (Stenger 2001, p. 992). This "pulling" to the distant unknown periphery of known mythical peoples, images and stories, previously located on the equally unknown

\footnotetext{
${ }^{2}$ The first detailed exposition of the legend is preserved in Herodotus (IV, 32-35), although some references to it are found in earlier writers. The legend of Hyperboreans is described in various ways by many ancient authors. On the significance of the Hyperborean topos for ancient geographic literature and on their localization, see more: Daebritz 1916, pp. 258-279; Harmatta 1955/1956, pp. 57-66; Dion 1976, pp. 143-157; Dion 1977, pp. 260-270; Ramin 1979, pp. 55-71; Romm 1989, pp. 97-113 Romm 1992, pp. 60-67; Kyriazopoulos 1993, pp. 395-398; Werhahn 1994, pp. 967986; Lazova 1996; Bridgman 2005, pp. 27-98; Rausch 2013, pp. 49-55, 77-80.
}

periphery of the known world which became familiar during the centuries, is very typical for the Greeks and Romans.

Speaking of the relationship between Riphaeans and Hyperboreans, it must be pointed out that the very name of the Hyperboreans could have passed to the Riphaean Mountains, which were sometimes called the Hyperborean mountains. So Servius in Scholia to Verg. Aen. XII, 366 writes: "certum sit eum (sc. Boreas) de Hyperboreis montibus flare" - "Certainly it (i.e. Boreas) blows from the Hyperborean mountains"; Schol. Bern. ad Verg. Georg. III, 196: "Hyperborei montes in Scythia, inter quos Aquilo inflat" - "Hyperborean mountains are in Scythia, Aquilon blows there"; Schol. ad Stat. Theb. V, 390: "Hyperborei enim montes trans Aquilonem sunt" - "Hyperborean mountains are situated behind Aquilon".

According to Apollinarius Sidonius (5th century $A D$ ), the terrible tribe of the Huns left the "Scythian land" where "the white Tanais, flying from the Hyperborean mountains, falls from the Riphaean rocks, under the axis of the Bear" (Carm. II, 235-298).

In the "Cosmographia" of Julius Honorius (4th-5th century), the Riphaean mountains and the Hyperborean mountains also do not differ (see A 30 and 33: Fluvius Tanais nascitur de monte Hyperborei Ripaei). Since "Cosmographia" is a geographical nomenclature that has been written off the map (Podossinov 2002, 107-111), it can be assumed that the author could not determine which inscription refers to the mountains (Riphaeans), and which to the people (Hyperboreans).

The westernmost point where, according to the ancient tradition, Hyperboreans could be placed, should be found somewhere in the west of Europe.

Diodorus of Sicily, retelling Hecataeus of Abdera, places Hyperboreans on an island in the Atlantic ocean behind Celtica, that is practically in the northwest of Europe (Diodor. II, 47: $\dot{\varepsilon} \mathrm{V}$

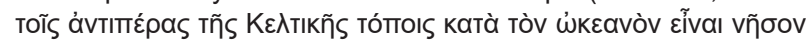

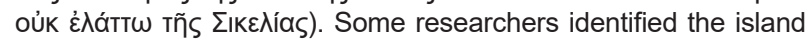
of Hyperboreans with Britain and the round temple of Apollo of Hyperboreans, mentioned by Hecataeus, with Stonehenge; others, with Jutland. On this island, swans came flying on the holidays from the Riphaean Mountains, which turn out to be in the same place in Celtica. Ptolemy also calls the ocean north of Ireland "Hyperborean" (Geogr. II, 2, 1: 'Арктікñ

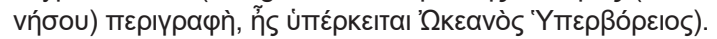

According to Pindar (OI. III, 13-16) and Aeschylus (Prom. Vinct. 21, 31, 75, 119), the Hyperboreans lived near the sources of river Ister (Danube); according to Posidonius (87 F 103 Jacoby = Schol. Apoll. Rhod. II, 675), near the Alpine mountains in Italy. A certain Protarchus (an author, probably in the first century BC, who wrote about the geography and early history of Italy) considered the Alps to be the Riphaean Mountains, behind which

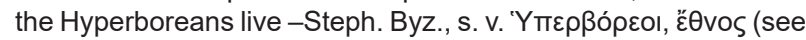
an overview of the localizations of the Riphaean Mountains in ancient literature: Beckers 1914, pp. 534-557; Lasserre 1979; see also: Ballabriga 1986, pp. 243-244; Bridgman 2005, pp. 20-74). Some other Greek writers (for example, Pytheas of Massalia or Apollonius of Rhodes) show the same localization of Hyperboreans.

\section{The Riphaean in Asia}

If we move further to the east of Eurasia, it should be remembered that there is also a point of view according to which Riphaeans were initially located in the Caucasus, which was called Ripa. Modern scholars think that "Hecataeus first divided these concepts - the Riphaeans and the Caucasus - placing the first to the north of the second" (Yel'nitskiy 1961, p. 60).

Some researchers (e.g. Bolton 1962, p. 1-2) place Hyperboreans in Central Asia or even in China, based on the tribes' settlement described by Aristeas of Proconnesos in his poem "Arimaspea" (6th century BC). 
An interesting report on the Asian localization of Hyperboreans was left by Pliny the Elder: after his description of the "European" Hyperboreans, he observes (IV, 90): "Some authorities placed these people (Hyperboreans) not in Europe but in the nearest part of the coasts of Asia, because there is a race there, with similar customs and a similar location, named Attac(or)i" (transl. by H. Rackham)

Attacori is an ethnonym, attested in this form only by Pliny. He mentions them once again in the 6th book of "Historia Naturalis" (VI, 55) on the east coast of Asia (practically in the Chinese region!), pointing to the similarity of their customs with the customs of the Hyperboreans: they live "with the same temperate climate as that in which dwell the Hyperborei. The Attacorae are the subject of a monograph by Amometus, while the Hyperborei have been dealt with in a volume by Hecataeus" (transl. by $\mathrm{H}$. Rackham).

It is possible that in this ethnonym (Attacorae), the name of the blessed people Uttarakuru was reflected (Uttarakuru - literally "northern Kuru" were known in ancient Indian literature) in some Puranas, "Mahabharata" (IV, 43) and "Ramayana" (VI, 7) (Bolton 1962, p. 98). These people were placed north of the Himalayas (the sacred Mount Meru in India), where a mild climate reigns and fertile land provides everything necessary for life, so that the Uttarakuru are free from physical labor, and spend their lives in peace and joy until old age.

It is supposed that from India this information could come into Greek literature after Alexander's eastern campaigns, for example, through the official of the diadoch Seleucus Megasthenes, who in his work "Indica" already identified the Hyperboreans with them; see Strabo (XV, 1, 57): "Concerning the Hyperboreans, who live a thousand years, Megasthenes says the same things, as Simonides and Pindar and other myth-tellers" (trans. by H. L. Jones) (see also: Tomaschek 1888, p. 771; Herrmann 1942, pp. 1888-1889; Daebritz 1916, p. 272; Bolton 1962, pp. 98-99).

These views on the localization of Hyperboreans could long maintain in antiquity the broad and abstract idea of Riphaeans in northern Europe and Asia, from the Alps to the Tien Shan and even China; disputes about the localization of Riphaeans still occupy the minds of researchers. In every case we must accept, that "the Riphaean mountains are an image of the oldest mythology, one of the elements of the world picture, worked out by mythological cosmology, but this image was embodied in many real mountain ranges" (Pyankov 1978, p. 48; see also: Thomson 1948; Romm 1992, pp. 60-67).

\section{The Riphaean Mountains in Northeastern Europe}

One of the first mentions of the Hyperboreans indicates their localization, and therefore that of the Riphaeans, in Northeastern Europe in connection with the very concrete localization of the peoples, and descriptions of trade routes. This is how, for example, the Greek author Damastes (practically a contemporary of Herodotus) describes their location: "The Issedones live above

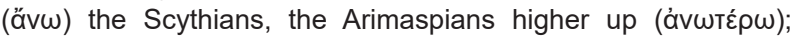
then the Rhipaean mountains, from which Boreas blows and snow never converges; and above them, Hyperboreans dwell till

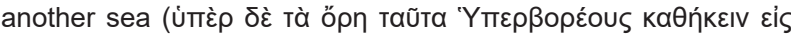

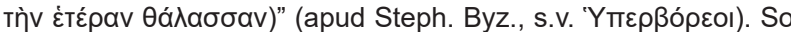
they are approximately placed in Herodotus (IV, 13 in retelling Aristeas), Pseudo-Hippocrates (On the airs, waters and places 19), Pomponius Mela (I, 12; III, 36) and Pliny the Elder (NH IV, 89-90; VI, 34).

It should be noted that, although ancient authors later on tried again and again to present Riphaeans as mountains that extend broadly throughout the north of Europe, in the Roman geographical tradition they firmly gain their place in the extreme northeast of Europe. Valerius Probus in the commentary to Verg.
Georg. III, 382, obviously arguing with supporters of the Alpine localization of Riphaeans, notes that "some people took the Riphaean mountains for the Alps. But the Riphaean mountains proper are in Scythia." The "Scythian" tradition was reproduced by Mela, Pliny, Solin, Julius Honorius, Paulus Orosius, other Latin authors, and in this form passed into the Middle Ages.

Already from Herodotus, the period starts when "serious" science began to doubt the existence of Hyperboreans and Riphaeans, considering the stories about them as fictions and myth-making (Eratosthenes, Apollodorus, Strabo, etc.), but not ignoring them entirely.

Thus, Aristotle in Meteorology (I, 13, $350 \mathrm{~b})$ supports the Scythian localization of Riphaeans, although he regards as "fabulous" the notion of their magnitude: "In the extreme north, beyond furthest Scythia, are the mountains called Rhipae. The stories about their size are altogether too fabulous..." (transl. by J. Barnes).

In ancient geography, it was widely believed that all rivers have their origin in the mountains. The Greek and Roman geographers believed that the rivers flowing from the north to the Black Sea flowed off the Riphaean mountains. For Greeks, living in a country where the sources of rivers are usually found in the mountains, it was difficult to imagine that the huge, deepwater rivers of the Northern Black Sea coast do not start in the mountains. This was probably one of the reasons why the unclear information about the semi-mythical Riphaean mountains in Thrace after the colonization of the Northern Black Sea region, with its powerful rivers flowing from the north, could easily be transferred - with the expansion of the geographical horizon - to Northeast Europe (Beckers 1914, pp. 538-539). In addition, they now received some scientific confirmation.

Most minutely and perhaps for the first time, this idea was expressed by the first Roman composer of geographic work, Pomponius Mela: the Riphaean mountain rises behind the Arempheans, beyond this mountain is the North Ocean (I, 117); the Riphaean mountains stretch through the north of Eastern Europe (II, 1); they are inhabited by Hyperboreans (III, 36); the river Tanais (modern Don) originates from the Riphaean mountain $(I, 115)$. The connection of the Don-Tanais with the Riphaean mountains soon became as strong as the connection of Riphaeans with the Hyperboreans.

\section{Cosmological aspect of location of Riphaean Mountains}

Riphaeans and their location were actively discussed within the framework of cosmological and meteorological (in the ancient sense of the word) theories.

It should be noted that the Riphaean Mountains and the land of the Hyperboreans are linked to the supposed axis of the world (axis mundi). This is evidenced, in particular, by the constantly occurring assertion that Riphaean mount lies under the constellation of the Great Bear, which itself was perceived as the northern point of the world axis.

In antiquity, the theory of increasing the land to the north

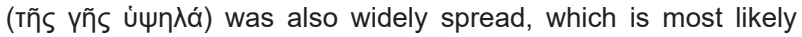
an allusion to the Riphaean mountains, because this theory is very closed connected with the doctrine of the existence of some space mountain (or mountains) in the far north, where the sun returns at night from west to east, hiding behind a high hill or mountain. The beginning of this theory lies in Ionian science (6th-5th centuries BC) and is connected with the idea of the earth as a disk or puck (Kiessling 1914, 846-856; Bekkers 1914, 535-537).

One of the earliest Ionian philosophers, Anaximenes, explicitly declared, that the sun does not pass at night under the earth but goes into hiding behind the sublime parts of the earth on the outskirts of the oecumene (see Anaximen. Fragmente

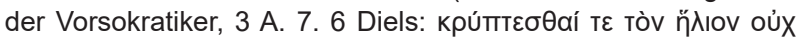




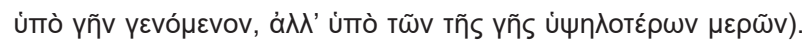
Aristotle in "Meteorology" (II, 1, 354a), referring apparently to the same Ionian scientists, localizes these uplands directly to the north: "Some further evidence of the height of the northern regions of the earth is afforded by the view of many of the ancient meteorologists. They believed that the sun did not pass below the earth, but round its northern part, and that it was the height of this which obscured the sun and caused night" (transl. by J. Barnes).

These theories happily survived to the Christian cosmological constructions of Cosmas Indikopleustes (6th century) in the east and the Anonymous from Ravenna (6th-7th centuries) in the west of medieval Europe - the constructions which, like in lonian science, were based on the idea of the earth as a flat circle or a quadrangle, like those by Cosmas. While Cosmas wrote only

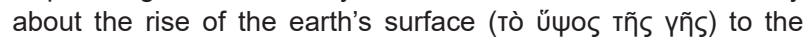
north and west, behind which the sun hides in the night (Topogr. Christ. 88C-89C; 185C-188D), the manuscripts of his "Christian topography" retained the image of the mountain in the north of Europe behind which the sun sets.

So Christian theology, denying the sphericity of the earth and the sky, the existence of Antipodes and other "achievements" of ancient science, retained the notion of the existence in the north of the flat land of the Riphaean mountains.

\section{The Riphaean Mountains in "Geography" of Ptolemy}

As for the mapping of Riphaeans in ancient cartography, it should be noted that very few artifacts have been preserved from antiquity - practically two or three maps, and only the map (or maps) of Ptolemy depicted the Riphaeans.

What does the rational scientist Ptolemy think about the mythical Riphaeans and their localization?

In the 3rd book of "Geography" (III, 5, 15 in: Klaudios Ptolemaios 2006) Ptolemy mentions several mountains in Eastern Europe (so called European Sarmatia), and among them the Riphaeans: "Sarmatia is crossed also by other mountains [apart from Sarmatian ones], between which are called:

Peuce mount

Amadoka mount

$51^{\circ}-51^{\circ}$

Bodinon mount

$59^{\circ}-51^{\circ}$

Alaunon mount

$58^{\circ}-55^{\circ}$

Carpathes mount, as mentioned

$62^{\circ} 30^{\prime}-55^{\circ}$

Venedian mountains

$46^{\circ}-48^{\circ} 30^{\prime}$

Riphaean mountains, the middle of which is

$$
47^{\circ} 30^{\prime}-55^{\circ}
$$

$$
63^{\circ}-57^{\circ} 30^{\prime} . "
$$

We see that Ptolemy has placed the Riphaean mountains in the northeast corner of European Sarmatia on his map. So, the mythical Riphaean mountains, the existence of which Herodotus, Eratosthenes, Apollodorus and Strabo doubted, found their place on the purely "scientific" map of Ptolemy. This shows only one thing - the deep implantation into the consciousness of ancient man of the idea that in the north of Eastern Europe, the certain Riphaean mountains exist.

The Hyperboreans of Ptolemy were cut off from the Riphaeans and almost turned into an epithet: in the north of Asiatic Sarmatia, Ptolemy places the Hyperborean mountains ( $\mathrm{V}$,

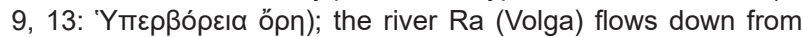

them and above them "Hyperborean Sarmatians live in the areas adjacent to the unknown land" $(\mathrm{V}, 9,16)$.

So, Ptolemy has depicted both mountains - Riphaean (in Europe), and Hyperborean (in Asia). If we consider that Ptolemy's Asiatic Sarmatia is part of modern Eastern Europe from the Don to the Urals, then both these mountains are still in Eastern Europe.

Conclusion: the fate of the myth in Medieval and New Time geography

The tradition of depicting the Riphaean Mountains was very lasting. Mythical Riphaeans quite often appear on medieval maps, impregnated with the Christian spirit. Moreover, these mountains were present even on very schematic maps with a small number of geographical objects, which indicates their importance in the minds of medieval cartographers. Riphaean mountains were constantly depicted as one of the most extreme points (or the most extreme) of the oecumene in the north. On medieval maps, Tanais-Don almost always originates in the Riphaean Mountains.

For the fate of the myth of the existence of the Riphaean Mountains, the work of the Polish historian and geographer Maciej z Miechowa (1457-1523), "On Two Sarmatians" (the first edition: Maciej z Miechowa 1517), is of great historical and symbolic significance. In this treatise he examines the contemporary history and geography of Eastern Europe and, in particular, of Rus.

Maciej was practically the first in Western European historiography to give readers relevant information about this region, vigorously protesting against the fantastic data of ancient authors about Eastern Europe, rejecting their stories about blessed Hyperboreans, Arimaspi and griffins, about two-headed, dog-headed and one-eyed people, about the horrors of winter, and finally about the Riphaean and Hyperborean mountains, while giving the Slavic names to those rivers that everyone knew from Ptolemy (see Piechocki 2015, pp. 76-96).

Here is what Maciej writes in the Introduction to his treatise:

\footnotetext{
Many writers ... claimed that in those northern regions are situated the most famous mountains in the world - Riphaean and Hyperborean, and from them no less glorious rivers flow, described and sung by cosmographers and poets: Tanais, Great and Small Borysthenes and Volga - the greatest of the rivers. All this is far from the truth, and it will be not superfluous, based on experience (our universal teacher), to refute and reject this as an ignorant and unverified message ... That there are no mountains there, called Hyperboreans, Riphaean and Alanean, we know this most precisely and see (Montes autem Hyperboreos, Ripheos et Alanos nuncupatos illic non existere certo certius scimus et videmus), that the aforesaid rivers arose and have their origins in the plain.
}

Thus, the ancient myth was dethroned - that of the existence in the north of Eurasia of the mysterious Riphaean Mountains, behind which the blessed people of the Hyperboreans live in warmth and joy. But the legend has remained - the warm and fertile land has been sought over the last two hundred years in the Arctic Ocean; modern people write books about this land, make films, hold scientific conferences. 


\section{References}

Ballabriga, A 1986, Le Soleil et le Tartare. L'image mythique du monde en Grèce archaïque [The Sun and the Tartarus. The mythical image of the world in archaic Greece], Paris: Éditions de l'EHESS.

Beckers, WJ 1914, 'Die rätselhafte Hochgebirge des Altertums, die sogenannten Rhipäen' ['The enigmatic high mountains of antiquity, the so-called Rhipeans'], Geographische Zeitschrift, vol. 20, no. 9/10, pp. 534-557.

Bolton, JDP 1962, Aristeas of Proconnesus, Oxford: Clarendon Press.

Bridgman, T 2005, Hyperboreans: Myth and History in CelticHellenic Contacts, New York and London: Routledge.

Casson, S 1920, 'The Hyperboreans', The Classical Review, vol. 34 , pp. 1-3.

Daebritz, H 1916, 'Hyperboreer' ['The Hyperboreans'], Paulys Realencyclopädie der classischen Altertumswissenschaft, vol. 9, no. 1 , pp. $258-279$.

Dion, R 1976, 'La notion d'Hyperboréens: ses vicissitudes au cours de l'antiquité' ['The notion of Hyperboreans: their vicissitudes during antiquity'], Bulletin de l'association G. Budé 1976, p. 143-157.

Dion, R 1977, Aspects politiques de la géographie antique [Political Aspects of Ancient Geography], Paris: Belles lettres.

Harmatta, J 1955/1956, 'Sur l'origin du mythe des Hyperboréens' ['On the origin of the myth of the Hyperboreans'], Acta antiqua Academiae Hungaricae, vol. 3, pp. 57-66.

Herrmann, A 1942, 'Ottorocorrai' [Ottocores], Paulys Realencyclopädie der classischen Altertumswissenschaft [Pauly's Realencyclopaedia of Classical Antiquity], vol. 36, no. 3, pp. 1888-1889.

Kiessling, E 1914, 'Pímaı́ öpn' [Ripaean mountains], Paulys Realencyclopädie der classischen Altertumswissenschaft [Pauly's Realencyclopaedia of Classical Antiquity], vol. 1 (2nd series), pp. 846-916.

Klaudios Ptolemaios, 2002, 'Klaudios Ptolemaios' in Handbuch der Geographie. Griechisch-Deutsch., 1-2, eds A. Stückelberger \& G. Graßhoff, Basel: Schwabe Verlag.

Kyriazopoulos, A 1993, 'The Land of the Hyperboreans in Greek Religous Thinking', Parnassos, vol. 35, pp. 395-398.

Lasserre, F 1979, 'Rhipaia ore', Kleine Pauly. Lexikon der Antike in fünf Bände, vol. 4, pp. 1417-1419.

Lazova, T 1996, The Hyperboreans. A Study on the PalaeoBalkan Tradition, Sofia: St. Kliment Ohridski University Press.

Macurdy, GH 1916, 'The Hyperboreans', Classical Quarterly, vol. 30, pp. 180-183.

Maciej z Miechowa 1517, Tractatus de duabus Sarmatiis Asiana et Europiana et de contentis in eis, Cracoviae.

Piechocki, K 2015, 'Erroneous mappings: Ptolemy and visualization of Europe's East', Early Modern Culture of Translation, Philadelphia (Pennsylvania): University of Pennsylvania Press, pp. 76-96.

Podossinov, AV 2002, Vostochnaya Evropa V rimskoy kartograficheskoy traditsii [Eastern Europe in the Roman cartographic tradition], Moscow: Indrik (in Russian).
Podossinov, AV 2015, Kuda plaval Odissey? O geograficheskikh predstavleniyakh grekov archaicheskoy epokhi [Where sailed Odysseus to? To the geographical concepts of the archaic Greeks]. Moscow: Yazyki slavyanskoy kultury (in Russian).

Pyankov, IV 1978, 'Rifei - mif i real'nost'['Riphaia, is it myth or reality'], Ural'skiy sledopyt [Uralean traker], vol. 8, pp. 44-48 (in Russian).

Ramin, J 1979, Mythologie et géographie [Mythology and geography], Paris: Belles Lettres.

Rausch, S 2013, Bilder des Nordens. Vorstellungen vom Norden in der griechischen Literatur von Homer bis zum Ende des Hellenismus [Pictures of the North. Concepts of the North in Greek literature from Homer to the end of the Hellenism]. Darmstadt: Philipp von Zabern.

Romm, J 1989, 'Herodotus and mythic geography: The case of Hyperboreans', Transactions of the American Philological Association, vol. 119, pp. 97-113.

Romm, J 1992, The edges of the earth in ancient thought: Geography, exploration and fiction, Princeton: Clarendon Press

Stenger, J 2001, 'Rhipaia ore', Der neue Pauly, vol. 10, pp. 992-993.

Thomson, JO 1948, History of Ancient Geography, Cambridge: Cambridge University Press

Tomaschek, W 1888, Kritik der ältesten Nachrichten über den Skythischen Norden. I. Über das Arimaspische Gedicht des Aristeas ['Criticism of the oldest evidence about the Scythian north. I. About the Arimaspean poem of Aristeas], Sitzungsberichte der Kaiserlichen Akademie der Wissenschaften. Philos.-histor. Klasse, Wien, vol. 116.

Werhahn, HM 1994, 'Hyperboreer' ['The Hyperboreans'], Reallexikon für Antike und Christentum, vol. 16, pp. 967-986

van Windekens, AJ 1957, 'Les Hyperboréens' ['The Hyperboreans'], Rheinisches Museum, vol. 100 (NF), pp. 164-169.

Wikén, E 1939, 'Die Ansichten der Hellenen über den Nordrand der Oikoumene vor Pytheas: Rhipaien und Hyperboreer' ['The Hellenes' views of the northern edge of the oikoumene before Pytheas: Rhipean and Hyperboreans'], $\triangle$ РАГMA, Festschrift für Martin P. Nilsson, Lund, pp. 540-552.

Yel'nitskiy, LA 1961, Znaniya drevnikh o severnykh stranakh [Knowledge of the ancients about the northern lands], Moscow: Gosudarstvennoye izdatel'stvo geograficheskoy literatury (in Russian). 